\title{
Topic in Case of Penology Execution of Criminal Sanctions in the Republic of Albania
}

\section{PhD Candidate Esmeralda Thomai}

\author{
Department of Law Pena list Branch, SEEU University, Macedonia; esmeraldathomai@yahoo.com
}

\author{
Doi:10.5901/ajis.2015.v4n3s1p188
}

\section{Abstract}

After the 1990 reform of the penitentiary system in Albania included all aspects of the system: reform in the legal system, reform of the administration, the way of organizing. It is a major role in the reform process has played the Council of Europe, which drew up concrete programs and managed the legal and institutional reform. Currently operating in Albania are 13 prisons and four other construction stageCriminal Code of the Republic of Albania was approved in 1995, Law no. 7895, dated 27.01.1995. For the first time the new code was predicted alternatives to imprisonment in chapter VII of its General Part. Although the doctrine recognizes alternatives to criminal penalties, the title of the code still talks about alternatives to imprisonment, even after legal changes that were made in 2008 to reform the alternative measures 1.

Keywords: Albanian criminal code, criminal penalties, cases of violations.

\section{Introduction}

Criminal Code of the Republic of Albania was approved in 1995, Law no. 7895, dated 27.01.1995. For the first time the new code was predicted alternatives to imprisonment in chapter VII of its General Part. Although the doctrine recognizes alternatives to criminal penalties, the title of the code still talks about alternatives to imprisonment, even after legal changes that were made in 2008 to reform the alternative measures ${ }^{2}$.

The Criminal Code of the Republic of Albania provides these type penal punishments:

a - The main penalties:

- The punishment with life imprisonment,

- The punishment of imprisonment and

- The punishment with fine (punishment of life imprisonment imposed only against the perpetrators, and the sentence of imprisonment or a fine he also imposed against perpetrators of violations (Article 29 of the Criminal Code).

b - Supplementary Penalties which can be provided together with the main punishment to persons who have committed crimes or criminal offenses (Article 30 of the Criminal Code)

c - Alternatives to imprisonment (Articles 58,59,59/a, 63.64 CC)

d - Medical and educational measures (Article 46 of CC)

\subsection{Types of penalties under the Criminal Code of Albanian Republic}

In 1995, the Penal Code foresaw four types of alternatives to imprisonment, the imposition of which was the basic requirement, the court had appointed prison sentence to the convicts. These alternatives were:

1. Fragmentation of imprisonment (Article 58)

2. Suspension of imprisonment and put on probation - known as penalty

3. Proviso (Article 59);

4. Suspension of execution of sentence of imprisonment and compulsion to perform work in the public interest (Article 63)

5. Release on parole (Article 64). 
The presentation of these alternatives was not associated with executive structure necessary for supervising their implementation. This absence is defined as the dominant factor in poor practical implementation of these alternative measures of Albanian court jurisprudence. Due to the lack of supervisory structure, equal alternative measures perceived effects of decisions to dismiss criminal proceedings or decisions of innocence. ${ }^{3}$

Through the changes introduced by Law no. 10023 dated 27.11.2008 "On some amendments to Law no. 7895, dated 27.01.1995 "Criminal Code of the Republic of Albania 'changed', already has five options::

"Semi freedom" (Article 58 ');

"Suspension of the execution of a sentence and put on probation" (Article 59);

"Stay at home" (Article 59 / a);

"Suspension of the execution of imprisonment and compulsion to perform work in the public interest" (Article 63); and "Parole" (Article 64).

So, there are presented two new alternatives, one of which replaced the fragmented alternative sentencing, and is changing the content of the three existing alternatives (despite the fact that they were in the alternative, is the same).

\section{Literature Review and Hypotheses}

The way,how a state punishes those who commit crimes and how executes sentences given to them is undoubtedly indicative of its civilization.

The answer to the question, is how contemporary reality penal sanctions against persons convicted, is always a matter related to critical reviews of legislation are the legal basis for the execution of criminal sanctions as well as relevant surveys conducted at institutions penitentiary.

To make an objective analysis regarding how criminal sanctions actually executed in Albania, we have to deal with many components that have to do not only with the reading of laws and regulations applicable at this stage of the procedure, but the study also reports and monitoring results penitentiary system links with the implementation of the suggestions study reports international partners, to study the level of coordination of the system, the existence of staff, etc.

It requires that all analyzes and deductions you answer the question:

Is it effective the last stage of the criminal proceedings? Is it good or bad managed the penitentiary system to all categories of prisoners?

Does it the approach exist and how much access is there to international standards?

After 90 years of all Albanian legislation and the justice system was "subject to" a process of continuous reform. After ratification of the ECHR and after the adoption of the Constitution in 1998, reform the legal system and criminal justice in that size was not only quantitative but also qualitative. These as well as other documents enabled the safe path towards well-defined standards.

This reform has not really ended. We are still unsure if the penitentiary system works well and challenges to achieve the best are increasingly raised.

It is necessary that the penitentiary system in every stage should respond to the demands of the present and future prospects, in order to laws and regulations, to the penitentiary procedures, to the institutions involved in the stage of execution of criminal sanctions and is convicted, which should be worth a lot of rehabilitation of convicts and prisoners.

In the system of execution of criminal sanctions execution of a sentence of imprisonment, a fine and penalties as alternative measures to imprisonment, occupy primary place. For this reason, the object of this subject in the course of Penology will be the way of the execution of these three types of sentences in Albania.

\section{Execution of the Sentence of Imprisonment}

After the 1990 reform of the penitentiary system in Albania included all aspects of the system: reform in the legal system, reform of the administration, the way of organizing.

It is a major role in the reform process has played the Council of Europe, which drew up concrete programs and 
managed the legal and institutional reform. Currently operating in Albania are 13 prisons and four other construction stage. ${ }^{4}$.

In 2009 it approved the decision by Ministry Council "General Regulation of Prisons", a normative act that defines the way of exercising the rights and obligations of prisoners, whether sentenced to imprisonment or detained, the organization of their life, the manner and conditions penitentiary imprisonment, the development of the activity of work and remuneration for work performed, as well as the functioning of the Directorate General of Prisons and the institutions of the penitentiary. ${ }^{5}$.

In the framework of this regulation, the process of rehabilitation must pass through the implementation of vocational training programs, employment, education, participation in activities and sports and recreational activities, participation in providing library service in the institutions (Articles 77-88 of regulation).

\subsection{Employment}

Every institution of execution of criminal sentences (prison) has developed labor organs for prisoners, based on their needs and the requirements for inclusion in employment activities. According to the General Directorate of Prisons, the number of prisoners engaged in employment activity in January 2014 was 606 persons from 3125 that was the number of prisoners at the Institute of Serving Criminal Sentences in the country.

\section{Research Goal}

Prisons General Directorate notes that the, since 2010, working organs and specifically is designed for each IEPD by various crafts and daily cost of prisoners have not been completed, although it has been sent for approval to the Ministry of Justice since 2010. This ministry has not allocated funds for remuneration for prisoners labor and I think that this is a contributing factor to the exclusion of prisoners from the work process, which does not serve their rehabilitation process.

\subsection{The education}

In terms of education it can be said that in the institutions of Albanian education process is not performed as regulation requires them and international standards too. In the framework of the Stabilization and Association Agreement, among other things, is required as a measure implementing the reform of the penitentiary system and the establishment of schools opening in the penitentiary institutions of imprisonment. In 2008 between the Ministry of Justice and Education signed a memorandum of cooperation for the opening of cycle 9-year compulsory education in the prison system.

In academic year of 2012-2013 besides 5 schools in five prisons in the country, they opened 3 schools in the Minors Section into custody in Tirana, Vlora and Lezha and a school to Rrogozhina prison for adult convicts. According to data taken from the General Directorate of Prisons, in December of 2012 they registered schools were 228 convicted. The educational process of minors to 9-year compulsory education in the case of imprisonment decision that takes final form, according to the GDP, theoretically it is continued at the Institute of Minors in Kavaja.

Although the Law "On the rights and treatment of prisoners" pays attention the education of minors ${ }^{6}$, and in practice, compulsory education 9-year, juveniles or young people up to the age of 25 , due to lack of infrastructure, can not continue in their education progressively.

\subsection{The way prison sentences are executed for juveniles}

In Albania ways how are executed prison sentences for juveniles; it presents another problem, often raised as a concern by international partners.

Albania has not yet set up a fully functional management and for juvenile justice.

\footnotetext{
${ }^{4}$ Internet source, info@dpbsh.gov.al

${ }^{5}$ Approved by COM decision no. 303, dated 25.03.2009

${ }^{6}$ Article 37 determines that education and cultural and professional training done by the school organization, mandatory for minors, as well as vocational training, according to the applicable systems. Special attention is paid to cultural and professional training of prisoners under 25 years of age.
} 
In this country there are more separate pieces of a system, which are not clearly orientated. According to a study conducted in 2006 by the Center for Children's Rights in Albania with the support of the European Council for a review of the system of administration of for juvenile justice in Albania, the situation of children in prisons is still far from the required standards. Although, in recent years there has been a growing interest from public institutions responsible and donors to improve the infrastructure and management of these systems and still are persisted cases of violation of children's rights.

\section{Sample and Data Collections}

During the preparation of the study, the group of researchers met with over 80 minors and visited more than once a number of police stations, pre-trial detention and prison in the city of Shkodra, Lezha, Kruje, Burrel, Tirana, Durres, Lushnje Fier, Berat and Elbasan, Korca Librazhd etc.

The country has some prisons that accommodate and care for children. The prisons, a kind of two-floor building around $10 \mathrm{~km}$ from Tirana, has a male juvenile section. Over the years in this jail houses up to 30 children, but at the time of the study in this institution were only 14 minor. $^{7}$

Vaqarr Prison Juvenile section is almost separated from adults.

It is located on the left side, on the second floor of the building, adjacent to the prison library. Although apparently there are no concrete opportunity meeting adult prisoners with those children, because this section is not completely separate from prison, t happens that minors often meet with adults. This can happen mostly in showers and toilets, which are common, and in areas of the game, behind prison. ${ }^{8}$

Prison 325 in Tirana is a mixed prison security low, which is in the "Ali Demi" inside Tirana. A special section of this institution cares for women prisoners.

All the difficulties encountered in running the detention system and prisons have given their negative impact in terms of respect of the rights of children in these institutions.

Convention on the Rights of Children in principle should be applied directly to the places of detention and penitentiary of minors. However, there is a profound lack of knowledge of CRC from almost all staff working with children and juveniles in the prison environments.. This makes the implementation of the CRC in national laws and to respect the rights of children too hard. Under the Convention, States purposive Parties are required to enable adequate education, recreational activities, adequate food, health care and other social services for children. Meanwhile, the penitentiary institutions should guarantee freedom of information, expression and respect for the views-thoughts of children and minors. ${ }^{9}$

The observation mission of the Center for Children's Rights in Albania during the preparation of the study in question stated that there was no opportunity to meet with a girl-child in conflict with the law.

For reasons not studied yet a good number of girl-children performing infringement or offense in Albania remains extremely low. It can also be a positive sign of the traditional values that the family plays an mporant role in children growth.

According to experts, this is a phenomenon that requires a further analysis to explain the differences and causes between criminal behavior of boys and girls in Albania, in order to see why the gender group has a greater tendency than the other group to commit criminal offenses.

However, a major concern is the lack of adequate facilities for keeping children-girls in police stations, detention rooms and prisons. So far in Albania there is still no concrete action plan, in order to set up special areas for children-girls in conflict with the law.

The small number of girls, who are perpetrators of criminal acts, should not impede public officials to think about setting up adequate facilities for this genre. ${ }^{10}$

\footnotetext{
${ }^{7}$ Juvenile justice in Albania. Analysis of the management system of juvenile justice and the situation of minors in conflict with the law in Albania, 62

8 Juvenile justice in Albania. Analysis of the management system of juvenile justice and the situation of minors in conflict with the law in Albania,.62

${ }^{9}$ Juvenile justice in Albania. Analysis of the management system of juvenile justice and the situation of minors in conflict with the law in Albania, 62

${ }^{10}$ Juvenile justice in Albania. Analysis of the management system of juvenile justice and the situation of minors in conflict with the law in Albania. pp 63.
} 
For minors in prisons is implemented the Law "On the Rights and Treatment of

Prisoners "and the General Regulation of Prisons". Also, every prison has also its internal regulation, which is prepared in compliance with laws and regulations mentioned above.

There is still no specific regulations for the maintenance and care of juveniles in detention rooms and prisons, which makes difficult the recognition minors with all internal regulations of penitentiary institutions.

\subsection{Keeping the imprisonment of women}

In the prison system in Albania women appear to a sentence of imprisonment in Tirana, in two sections, which are located within two institutions: Prison 325 on the 'Ali Demi" street and 313 prison on the' Jordan Misja"street. ${ }^{11}$

According to statistics of 2009 in Prison no. 325 were 102 women, and 313 were in prison serving a sentence 45 women.

These sections within prisons where women serve their sentence, do not have any particular sub-section for the girl child. The small number of girl child who commit crimes in Albania, seems to have pushed the prison leaders not to create environments for the girl child in prisons. According to the General Directorate of Prisons the law allows convicted women who have children, at least 4 times a month.

For convicts(female) who have recently given birth at the prison that is in "Ali Demi " street has established a the nursery where mothers can stay with their babies three times a day at different times. For the neonatal is taking care a medical staff of 24-hour service.

In Albania is turned into a chronic problem the overcrowding of prison.

The latest amnesty, which was conducted in March 2014 had as main argument precisely overcrowding in prisons, after the 100th anniversary of the Declaration of Independence of the Albanian state, in 2012 a law was passed by Parliament a broad amnesty, as the result of which was spared further suffering punishment for a significant number of convicts.

\section{Execution of Fines}

In Article 467 of the Criminal Procedure Code of the Republic of Albania is determined that decisions containing the fine is enforced by the Bailiff Office. However, in Albania service execution processes, organized since 2008 as a private service through the licensing of private enforcement, the provisions of Law no. 10031 dated 11.12.2008 "Private Bailiff Service" does not contain any definition, for private bailiffs to execute criminal decisions of fines.

From my work as a lawyer for a period of 10 years during which I have had criminal record of fines, I found that the fine decisions mostly are executed there. This is a big cramp, which will be solved by finding appropriate ways through rigorous legal instruments.

State Office of Enforcement recent years is turned into an almost inefficient service. With the establishment of the private bailiff service, organizational and state enforcement almost halved. This change, besides not changing the legal framework is one of the factors that currently disable the penitentiary with a fine in Albania.

Criminal fines as a wealth punitive measure has a significant effect on the realization of the purpose of criminal punishment and enables prevention of criminal conduct.

In order to enable efficient connection with the execution of the penalties, Albania will need to enable a deep legal reform and institutional ones following the best examples of the system in European countries.

\section{Execution of Alternative Sentences}

Besides reforming the alternatives to imprisonment, I mentioned above, the creation of appropriate infrastructure for alternative sentencing supervision is another aim of the reforms that have been implemented in the penitentiary system in Albania after 1990. In 2008 in Albania State Institution was established Probation Service.12

In accordance with Law no. 10024/2008, adopted two sub-laws are of normative character:

11 Internet source, info@drbsh.gov.al

12 Law no. 10024 dated 27.11.2008 "On amendments and additions to Law no. 8331 dated 21.04.1998 "On the Execution of Criminal Judgments' 
1- Decision of the Council of Ministers no. 302, dated 25.03.2009 "On Approval of Regulation and "On organizing as well as Probation service functioning, the establishment of standards and procedures for supervision for execution of alternative sentences".

2- Minister of Justice Order no. 6325, date 31.07.200945 "On Approval of the Regulation" On Probation Service collaboration with NGOs and Mediation Service"

These regulations set out the rules of cooperation with the Probation Service and NGOs Mediation Service in order to ensure the supervision of persons sentenced to alternative measures; assisting prisoners to reeducate and integrated into society, as well as crime reduction and prevention.

According to the normative framework the Probation Service is charged not only to supervise the implementation of alternatives to imprisonment, but also help the proceeding (court and prosecution) for specialized explanation in terms of the substance of alternatives to imprisonment. The institution was renamed "Probation Service" launched by European models of legislation

Nomenclature relates to the basic function of this service: "supervision measures or obligations of prisoners at the time of trial as better alternatives to imprisonment for achieving educational purpose and her rehabilitation to the convicts".

Since the beginning of operation of the Probation Service in 2009 and by the end of 2013 the number of people who are placed with a court decision in one of the alternatives to imprisonment is about 9356 people. ${ }^{13}$

Their supervision implemented on the basis of individual treatment programs. If there would have been applied alternatives to imprisonment, then these 9356 persons would have been sentenced to prison in one of the institutions for the execution of criminal penalties (IEPD). Thus, in 2013, the number of those sentenced to alternative punishments was added to the number of convicts who were supervised by the Probation Service, in the whole country was 1939.

Alternatives given by the court often is "Suspension of imprisonment and placement on probation. With this alternative measure 7553 convicted were sentenced. Alternative measure "Parole" about 823 convicted, the "public interest work" about 798 convicts, "stay at home" about 181 convicted. The alternative "semi-liberty" remains unimplemented. This option is provided only on one occasion during the entire period 2009-2013. ${ }^{14}$

"Half freedom" as a new alternative aimed at alignment with the Council of Europe recommendations and the best traditions of the criminal legislation of European countries.

The term "semi-freedom" is borrowed from European legislation, in which used "semi-liberty". A rough terminology and its formulation used in the Criminal Code of Kosovo. Article 58 of the recast, which replaced

"Fragmentation of imprisonment" enforce a court decision provides up to one year in jail with "semi freedom".

Duties are performed at a time determined by the court outside the prison. With their termination in accordance with the court decision, the citizen convicted is back in prison. ${ }^{15}$

It can be said that in 5 years of work, the Probation Service is now a consolidated institution in the criminal justice system in Albania, which has significantly improved restorative justice in this country. The essence of the role of this service is that evaluation, prevention and treatments in order to reduce crime in society and increase safety for community living.

In the context of the criminal justice reforms in Albania, in March of 2013 was realized "Electronic surveillance." Implementing Institution is the Probation Service. Electronic surveillance is used for persons who are subject to the alternative penalties and punishments. Restrictions imposed by judicial decision supervised through the device, which is placed in the body of the convicted person.

Supervision realized by operating room set up for this purpose. The device communicates operating room exit from the allow area or entry into the restricted area. At the moment when a violation of provisions of court decision occurs the operating room confirms the incident and informs the relevant authorities.

Electronic Control provides a powerful system to reinforce the efficiency of the penitentiary for people who have limited mobility and can promote increased public safety by improving monitoring of individuals in the community. Restriction of movement can also help in imposing discipline and daily structure for the prisoners, In breaking criminal

\footnotetext{
${ }^{13}$ Internet Source, statistical data, the Probation Service, Tirana.

14 Internet Source, statistical data, the Probation Service, Tirana

${ }^{15}$ Drejtësia për të mitur në Shqipëri. Analizë e sistemit të administrimit të drejtësisë për të mitur dhe gjendjes së të miturve në konflikt me ligjin në Shqipëri, fq.41
} 
behavior traits and can enable participation in work activities, education or training. ${ }^{16}$

\section{Conclusions}

Making an objective analysis regarding how criminal sanctions actually are executed in Albania, we have to deal with many components, which have to do not only with the reading of laws and regulations applicable at this stage of the procedure, but even with the study of reports and monitoring results of penitentiary system links with the implementation of the suggestions study reports by international partners with the study the level of coordination system, of the staff existence, etc.

After 90 years of all Albanian legislation and the justice system was "subject to" a process of continuous reform. Reform the legal system and criminal justice in that there has been a quantitative dimension but also qualitative. Reforming laws and other acts adopted under them enabling safe journey towards well-defined standards. The reform has not really ended. We are still unsure if the penitentiary system works well and challenges to achieve the best are always raised up.

Penitentiary system needs at every stage to respond to the demands of today and the future prospects in order to laws and regulations, to the penitentiary procedures, to the institutions involved in the stage of execution of criminal sanctions and to every convicted, which should be valid in rehabilitation of convicts.

The process of rehabilitation of convicts serving a sentence of imprisonment in the penitentiary institutions must pass through the implementation of vocational training programs, employment, education, participation in activities and sports and recreational activities, participation in service that provides libraries in Institute of Criminal penitentiary. In Albania should critically be assessed the implementation of standards regarding the way the prison system is organized, how are distinguished the categories of prisoners while serving a sentence in facilities within the system, especially minors and women, how the process of education and employment of convicts and how the conditions for medical service and hygiene and sanitation.

One of the factors that currently disables the penitentiary with a fine in Albania is the lack of legal framework and failure to meet the State Office of Bailiff, which the establishment of the private bailiff service has diminished its function. Criminal fines wealth as a punitive measure has a significant effect on the realization of the purpose of punishment and enables restrictive prevention of criminal conduct.

In order to enable efficient connection with the execution of the penalties, Albania will need to enable a reform of the legal and institutional depth, following the best examples of the system in European countries.

The creation of appropriate infrastructure for supervising the alternative sentence is another aim of the reforms that have been implemented in the penitentiary system in Albania after 1990. In 2008 in Albania was created National Institute of Probation. Since the beginning of operation of the Probation Service in 2009 and by the end of 2013 the number of people who are placed with a court in one of the alternatives to imprisonment is 9356 people. The alternative "semiliberty" remains unmitigated giving only in a court case over a period of 5 years, although as an alternative to imprisonment it seeks alignment with the recommendations of the Council of Europe.

In the implementation of alternative sentences, electronic monitoring provides a powerful system to reinforce the efficiency of the penitentiary for people who have limited mobility and promotes increased public safety by improving monitoring of individuals in the community. Restriction of movement may also help in imposing a discipline and a daily structure for the prisoners, in breaking criminal behavior traits and can enable participation in work activities, education or training, which is a function of convicted rehabilitation for petty offenses.

\section{References}

Internet source, info@dpbsh.gov.al Internet source, Probation Service Tiranë,2014

Internet source, "About Electronic Surveillance", Probation Service Tiranë,2014

CRCA, "Juvenile justice in Albania. Analysis of the management system of juvenile justice and the situation of minors in conflict with the law in Albania" Tiranë 2006

Criminal Code of the Republic of Albania in 1995, changed

Criminal Procedure Code of RA, changed 
Law no. 9888, dated 10.03.2008 "On the Rights and Treatment of Prisoners" changed

Law no. 10031, dated 11.12.2008 "On the private bailiff service"

Law no. 10024/2008 "On Probation Service"

OSCE "Handbook for the application of alternatives to imprisonment" 2010

Order of the Minister of Justice no. 6325, dated 31.07.200945 "On approval of the regulation" On Probation Service cooperation with NGOs and Mediation Service "

Decision No.303, dated 25.03.2009 "General Regulation of Prisons"

Decision no. 302, dated 25.03.2009 "On approval of the Regulation" On the organization and functioning of the Probation Service and the establishment of standards and procedures for supervising the execution of alternative sentences' ventive measures for the salvation of companies rom failure. 